\title{
PROTECTION OF FOREIGN INVESTMENTS
}

\author{
Edwin Borchard ${ }^{*}$
}

I

It is commonly assumed that the quest for foreign exchange, including among other methods excessive tariffs, import quotas, embargoes, preferences, subsidies, licenses, exchange controls, clearing agreement, currency depreciation, multiple currency, barter deals and discriminations of all kinds, ${ }^{1}$ and similar methods of crippling international trade, were the voluntary means by which certain countries gained advantage over others, ${ }^{2}$ resulting ultimately in an artificial channeling of international trade and stagnation on a wide scale. It is not sufficiently observed that the unwise arrangements of the Treaty of Versailles in keeping down the subsistence level of certain countries while promoting that of others, had much to do with the difficulties created for trade in the period between the two wars. Indeed, a strong argument could be made to show that the support of such a phenomenon as Hitler by the German people was itself a product of that despair in which Central Europe found itself.

It is now proposed to lift the barriers to international trade by injecting into the blood stream a large amount of American funds through UNRRA, the Bank for Development and Reconstruction and the Monetary Fund of the Bretton Woods agreements, loans from the Export-Import Bank, whose lending power has been greatly increased, and similar "loans" and devices. At the same time the powers that be have planted in the system such a treaty as is contemplated by the Potsdam Declaration, which under the guise of reparations eradicates the distinction between private and public property, reintroduces the element of slave labor, amputates territory, compels migrations, and eliminates Germany ${ }^{3}$ as an industrial competitor. The same dispensation is contemplated for Japan.

Students of international relations look with trepidation upon this artificial de-

* LL.B., 1905, New York Law School; A.B., 1908, Ph.D., I913, Columbia University; LL.D., I925, University of Berlin, and I935, University of Budapest. Professor of Law, Yale University. Author of numerous books on international law and domestic law. Contributor of numerous articles in American and European legal periodicals.

${ }^{1}$ Speceh of Mr. Clayton, reported in New York Times, April 12, I946, p. I7.

'International Trade Policy of the United States and the British Loan (1946) 14 DEP'T OF STATE BurL. 515, 520: ". . . if the loan [to Great Britain] is not granted she has no other alternative but to attempt to form such a bloc and to extend her trade and financial agreements with every other country who will negotiate with her. ...

"We would each have to use devices such as bilateral clearing agreements, exchange controls, currency depreciation, tariff quotas, and the like. Neither Britain nor the United States wants this."

${ }^{3}$ Acheson, International Economic Cooperation: Necessity for the British Loan (1946) I4 DEP'T of State Buzl. 511 . 
struction of economic values. The question remains whether that destruction can be compensated by the loans made on American credit by the American taxpayer and whether any more hopeful prospect is to be found in present conditions than prevailed after the so-called first World War. Although the writer disclaims any authority to speak as an economist, experience indicates that the restoration of international trade, which implies the lifting of tariff barriers and other artificial and unilateral national methods, must operate coordinately and not disparately. In other words, if there is any serious intention to restore international trade, the attempt must be made on all fronts at approximately the same time. Otherwise, the effort becomes contradictory and is likely to fail. That is to say, it is insufficient to lend money which merely postpones the day of reckoning without effecting a fundamental cure in the conditions which brought about the disease involved.

Unless the peace treaties look to some recuperation of entire continents and particularly of great industrial areas, no amount of artificial aid can breathe life into a weakened system. UNO itself, based upon a theory that force can be used by certain powers to make peace prevail, is handicapped by the fact that incentives are furnished to the disinherited to resent the settlements made by the peace arrangements. In other words, the lifting of international trade barriers must be attacked on all fronts in a constructive way, and simultaneously, and not be handicapped by the fact that political arrangements make necessary the continuation of trade barriers. Under such circumstances loans become a stopgap only. Not only are they likely to be lost irrevocably, but the disease will be as acute after the loans arc exhausted as it was before they were made.

Some reference has been made to the peace treaties. Perhaps the writer can explain his meaning by the fact that peace treaties in the nineteenth and earlier centuries looked to a different object from the treaties now made. Indeed, one could say that the art of peace-making has become a lost art. In the nineteenth and earlier centuries the object of a treaty was rarely to eliminate the unsuccessful adversary, but while attempting to cure some of the evils which led to the war, to win back that adversary to the western system as soon as possible, leaving him with his means of livelihood and binding up the wounds of war as quickly as possible. The twentieth century, on the other hand, has seen two world wars in which passions were aroused beyond anything heretofore known. The result was that the object of the war became the subjugation of the enemy, so that he could never thereafter become a menace to the victorious powers. This has led to the destruction of industrial values and annihilation by bombardment from the air in a fashion unprecedented. It left in its train resentments and frustration which are hardly conducive to the hope that the spirit of peace can be restored to the hearts of men either in the countries of the vanquished or in the countries of the victors.

Besides, we have for the first time in $1945-6$ an important power which believes it finds advantage in the destruction of its competitors. There is, therefore, no universal desire to reconstruct the devastated regions, but on the contrary an assumed 
profit in the continued destruction of large areas. In the nineteenth century the economic system was accepted as valid, whereas today it is challenged by many countries under the leadership of Russia. This is a condition hardly conducive to the lifting of trade barriers. In addition, it may be observed that the docile condition of colonies can no longer be counted upon to maintain a fragile status quo. Asia is in revolt against its European masters and will probably throw off the yoke before the century is out. This creates new nationalisms which are hardly conducive to a dropping of trade barriers. Each country, as it reaches the stage of nationalism, seems likely to seek survival and the cultivation of the means deemed necessary to that end.

We must, moreover, note another phenomenon which affects the prospects of lifting trade barriers. There has been a peculiar silence on the subversion of law during two world wars in which no large power remained a neutral so as to keep the belligerents within legal restraint. Grotius observed this deterioration in 1625 during the Thirty Years' War. ${ }^{4}$ Belligerents in 1940 found it to their advantage, so they thought, to conduct the war on an unlimited scale without regard to the restraints exercised by law. As to each other the struggle reached so high a degree of lawlessness that not even the fear of reprisals restrained the belligerents in more than a minor degree. The writer leaves out of account completely the invention of the atom bomb with all its implications.

The theory of united force against an "aggressor," even if it is not seen on a wide scale, puts the fear of strangulation in every small country. The larger powers, the coercers themselves, are likely to maintain heavy armaments in order to fulfill their assumed duties as well as to protect themselves against each other. We are thus likely to conclude that Milton was right in suggesting that war breeds war, and far from witnessing that process of disarmament which should follow the elimination of a dangerous rival, we are witnessing a competition in armaments on a scale never before known. The abolition of neutrality alone eliminates the voice of law and reason in holding the belligerents within legal restraint and the assumption that a universal orgy will produce peace seems a contradiction in terms. Thus, by promoting force to a pinnacle never heretofore reached, the voice of law has become ever more silent. Were it not for the fact that the peaceful relations of states will continue from time to time to prevail and that they must conduct their relations according to a code many hundreds of years old, we might be led to the conclusion that international law itself has given way to force. There should be no doubt on the question that the force which is to constitute the governing rationale of international conduct hereafter will be used by the great powers, if at all, to perpetuate

t Said Grotius: "Throughout the Christian world I observed a lack of restraint in relation to war, such as even barbarous races should be ashamed of; I observed that men rush to arms for slight causes, or no cause at all, and that when arms have once been taken up there is no longer any respect for law, divine or human; it is as if, in accordance with a general decree, frenzy had openly been let loose for the commiting of all crimes," Grotius, De Jure Belli ac Pacis (I625) proleg. 28, Classics of INTERNatronal Law, No. 3, Vol. 2 (F. W. Kelsey, transl., London, 1925), p. 20. 
their will and not the objective rule of law, which by inference no longer exists. Force used by nations has always heretofore been identified as war. Can it reasonably be supposed that they will now use that force in the objective interests of peace?

\section{II}

To make the subject concrete, the writer will deal with only one aspect of the economic problem facing the world. Rules of law that prevail in international law have been largely developed because of their economic foundation and because the interests of trade predominate over the interests of unrestrained force. If trade is to be developed on a large scale, foreign investments and foreign private property must have the protection of law. Otherwise, no foreign investments are likely to be made, at least from private sources. The confiscation of private property because of conflict between nation and nation, is one of the most serious inroads upon the institution of private property that could well be imagined. As long ago as the eighteenth century, when trade was still conducted in sailing ships and had not reached its present proportions, Alexander Hamilton wrote two of his Camillus Letters in defense of Article ro of the Jay Treaty of I794. His argument against confiscation was so conclusive and classic that, while often repeated, it can truly be said that it has not been improved upon by others. He remarked: 5

"The right of holding or having property in a country always implies a duty on the part of its government to protect that property, and to secure to the owner the full enjoyment of it. Whenever, therefore, a government grants permission to foreigners to acquire property within its territories, or to bring and deposit it there, it tacitly promises protection and security....

"The property of a foreigner placed in another country, by permission of its laws, may justly be regarded as a deposit, of which the society is the trustee. How can it be reconciled with the idea of a trust, to take the property from its owner, when he has personally given no cause for the deprivation? ...

"There is no parity between the case of the persons and goods of enemies found in our country and that of the persons and goods of enemies found elsewhere. In the former there is a reliance upon our hospitality and justice; there is an express or implied safe conduct; the individuals and their property are in the custody of our faith; they have no power to resist our will; they can lawfully make no defence against our violence; they are deemed to owe a temporary allegiance; and for endeavoring resistance would be punished as criminals, a character inconsistent with that of an enemy. To make them a prey is, therefore, to infringe every rule of generosity and equity; it is to add cowardice to treachery....

"Moreover, the property of the foreigner within our country may be regarded as having paid a valuable consideration for its protection and exemption from forfeiture; that which is brought in commonly enriches the revenue by a duty of entry. All that is within our territory, whether acquired there or brought there, is liable to contributions to the treasury, in common with other similar property. Does there not result an obligation to protect that which contributes to the expense of its protection? Will justice sanction,

\footnotetext{
${ }_{5}$ Works of Alexander Hanilton (Lodge's ed. 1885-6) 414, 415, 416-418. See the extended quotations from Hamilton and the references to the treaties concluded by the United States in Joun Bassett MOORE, International. Law and Some Current Illusions (1924) 14 et seq.
} 
upon the breaking out of a war, the confiscation of a property, which, during peace, serves to augment the resources and nourish the prosperity of a state?"

In his Camillus Letter XVIII, Mr. Hamilton stated $:^{6}$

"No powers of language at my command can express the abhorrence I feel at the idea of violating the property of individuals, which, in an authorized intercourse, in time of peace, has been confided to the faith of our Government and laws, on account of controversies between nation and nation. In my view, every moral and every political sentiment unite to consign it to execration."

Some inroad upon the institution of private property was adumbrated in Article 297 of the Treaty of Versailles. But that Article gave the nations only an option to confiscate of which some, unfortunately, took advantage. As the writer understands the Potsdam Declaration, it confers no option but purports to make the confiscation of private property in the enemy country and in the home country of the victor obligatory. Not only this, but the victors have imposed the obligation of surrendering private property upon the neutrals under threat of such sanctions, e.g., blacklists and "freezing" of assets, as they could impose on neutrals. If they are successful in this quest it will indicate that the neutrals no longer are sovereign states but mere appendages of the belligerent powers and function without regard to law under domination of the Great Powers.

The rule that private property is immune from confiscation is established not only in modern international law, ${ }^{7}$ and in the annex to Article IV of the Hague Convention, but is the product of a long historical process which realized that trade and confiscation were incompatible. Down to the eighteenth century confiscations occasionally occurred, but it was realized that trade could not go on under this dispensation. As early as I2I5 Magna Charta had perceived that foreign merchants must be given protection for their property on a basis of reciprocity, ${ }^{8}$ in the event of the outbreak of war. While this principle was not easy to adopt it became a more or less established practice after the Reformation and the origin of the state system in I648. Napoleon was one of the last to use confiscation, although he did it sparingly. The nineteenth century had become completely convinced of the economic importance of preserving private property against all contingencies, even war. Such a rule stimulated the making of foreign investments, direct and indirect.

During the last war there were some sacrificial sales made by the Alien Property Custodian and some effort was made to destroy the values in his possession. With

'5 Works of Alexander Haxilton (Lodge's ed. I885-6) pp. 405-406.

7 Borchard, Enemy Private Property (Ig24) 18 AM. J. INT. L. 523.

${ }^{8}$ Article 4I read: "All Merchants shall have safety and security in coming into England, and going out of England, and in staying and in traveling through Engand, as well by land as by water, to buy and sell, without any unjust exactions, according to ancient and right customs, excepting in the time of war, and if they be of a country at war against us: and if such are found in our land at the beginning of a war, they shall be apprehended without injury of their bodies and goods, until it be known to us, or to our Chief Justiciary, how the Merchants of our country are treated who are found in the country at war against us; and if ours be in safety there, the others shall be in safety in our land." Boyd C. Barrington, Magna Charta and Other Great Charters of England (igo0) 239-240. 
reference to the confiscatory policy thus subtly reflected, John Bassett Moore has remarked: ${ }^{9}$

"In the original statute the function of the alien property custodian was defined as that of a trustee. Subsequently, however, there came a special revelation, marvelously brilliant but perhaps not divinely inspired, of the staggering discovery that the foreign traders and manufacturers whose property had been taken over had made their investments in the United States not from ordinary motives of profit but in pursuance of a hostile design, so stealthily pursued that it had never before been detected or even suspected, but so deadly in its effects that the American traders and manufacturers were eventually to be engulfed in their own homes and the alien plotters left in grinning possession of the ground. Under the spell engendered by this agitating apparition, and its patriotic call to a retributive but profitable war on the malefactors' property, substantial departures were made from the principle of trusteeship....

"The subject has also another aspect. During the past ten years the investments abroad by citizens of the United States have enormously increased, and the process has only begun. Considering the question, therefore, purely as one of selfish calculation, I venture to think it directly contrary to the interests of the United States to resuscitate the doctrine that enemy private property found in a country on the outbreak of war may be confiscated. Such a doctrine might even create a temptation.

"But there is yet another and higher reason. The United States has an honorable past as well as an expedient future to consider.

"Of all the illusions a people can cherish, the most extravagant and illogical is the supposition that, along with the progressive degradation of its standards of conduct, there is to go a progressive increase in respect for law and morality. Again may we remark that 'there is no new thing under the sun.' The world never will be rid of the problem of preserving its elementary virtues. Three hundred years ago Grotius declared that, as he who violated the laws of his country for the sake of some present advantage to himself, 'sapped the foundation of his own perpetual interest, and at the same time that of his posterity,' so the people that 'violated the laws of nature and nations' broke down 'the bulwarks of its future happiness and tranquillity."

"No less pertinent is the confession of Alexander Hamilton, made a century-and-aquarter ago, that, serious as the evil of war had appeared to him to be, yet the manner in which it might be carried on was in his eyes 'still more formidable.' It was, said Hamilton, 'to be feared that, in the fermentation of certain wild opinions, those wise, just, and temperate maxims, which will forever constitute the true security and felicity of a state, would be overruled,' and that, one violation of justice succeeding another, measures would be adopted which even might 'aggravate and embitter the ordinary calamities of foreign war." "

Yet in this war we find that standards of public morality have so far been reduced that the Alien Property Custodian has authored a bill ${ }^{10}$ empowering the United States to confiscate the private property of Germans, Japanese, and possibly Italians in the Custodian's possession. A hearing on this bill was held April I7, I946.

${ }^{\circ}$ Moore, op. cit. supra note 5, at 22, 24-25; 6 Collected PApers of John Bassett Moore (1945) 27, 28-29.

${ }^{10} \mathrm{~S}$. 1322, 79th Cong., Ist Sess. (1945): "A Bill to amend the Trading with the Enerny Act, as amended, and for other purposes." 
As against this confiscatory policy of the Alien Property Custodian, we may print two extracts from recent Secretaries of State. Said Secretary Hughes in his address at Philadelphia November 23, I923:11

"A confiscatory policy strikes not only at the interest of particular individuals but at the foundations of international intercourse, for it is only on the basis of the security of property, validly possessed under the laws existing at the time of its acquisition, that the conduct of activities in helpful cooperation, is possible.... Rights acquired under its laws by citizens of another State, [a State] is under an international obligation appropriately to recognize. It is the policy of the United States to support these fundamental principles."

As recently as May 27, I935, Secretary Hull stated in a letter to Senator Capper:12

"Such action would not be in keeping with international practice and would undoubtedly subject this Government to severe criticism. Moreover, the confiscation of these private funds by this Government and their distribution to American nationals would react against the property interests (some very large) of American nationals in other countries. It would be an incentive to other governments to hold American private property to satisfy claims of their nationals against this Government and to pass upon such claims in their own way. It is important from my point of view, therefore, that the United States should not depart in any degree from its traditional attitude with respect to the sanctity of private property within our territory whether such property belongs to nationals of former enemy powers or to those of friendly powers. A departure from that policy and the taking over of such property, except for a public purpose and coupled with the assumption of liability to make just compensation, would be fraught with disastrous results."

If the conception is now to prevail that war is to be levied upon non-combatants, the so-called total war which excuses all lawlessness, the human race will have deteriorated beyond redemption. We shall find its first evidence in the fact that foreign investments will be made with great reluctance. And rarely will this be done by private bankers, who will not risk a long-term loan on such a precarious political position as now faces the world accompanied by the rule that confiscation is the penalty of belligerency. Possibly it is for that reason that we already find that such loans as are made are made from country to country, with all their political implications and at the expense of the taxpayer. The whole economic system is disrupted at the source by discouraging foreign investment. That was one of the main reasons for the rule of immunity of private property. With the breaking of that rule the result is not likely to remain outstanding.

It seems, therefore, unwise to expect the lifting of trade barriers on a wide scale and on any permanent footing so long as we make the underlying conditions diffcult for trade. One of these conditions is the free flow of capital from country to country, and if the system of private enterprise has any validity whatever, from private reserves. The rule of confiscation invalidates at the source any hope for

11 Borchard, op. cit. supra note 7, at $53 \mathrm{I}$.

${ }^{19}$ Borchard, Confiscations: Extraterritorial and Domestic (1937) 21 AM. J. INT. L. 680. 
foreign private investment, and for that reason seems likely to frustrate our larger aims.

This survey will have indicated that the lifting of trade barriers is associated with the lifting of all the other restrictions upon international trade, including the political, and that unless these measures have a constructive orientation, the result is likely to be one-sided, and eventually unsuccessful. To deal successfully with the subject, therefore, requires a re-examination of the methods used in recent years to safeguard private property.

\section{III}

From the table printed below ${ }^{13}$ the Bureau of Foreign and Domestic Commerce of the Department of Commerce calculated that in September, 1944, this country had abroad in direct investment $\$ 7.3$ billions, and in indirect investments some $\$ 4$ billions. This was not, however, adequate to offset the foregin investments in the United States which, direct and indirect, amounted to some $\$ 12$ billions, leaving on total balance a deficit of $\$ 1.2$ billions. In other words, by reason of the extraordinary amount of Lend-Lease expenditures, very little of which will be repaid, the expenditure of dollars abroad through our armed forces and the refugee capital which sought refuge in this country from the European holocaust, the United States, at least temporarily, has become a debtor nation again. That, however, is only an incident of the larger question of whether it seems likely that the American investor abroad will feel justified in making direct and indirect investments hereafter. From what has been said it will be concluded that the political risks attending a foreign investment are now so great that the national investor is likely to hesitate to make a foreign investment, direct or indirect.

Some of these political handicaps warrant examination. Reference has already been made to the risk he runs of the confiscation of his property in the event this country goes to war, unfortunately an ever present possibility in the light of our new policy of intervention. We have observed the economic warfare which handicapped the trader during the $1933^{\circ}$ 's. The need of ending such warfare is recognized on every hand. Yet that warfare received impetus in the economic policies during and

${ }^{13}$ International Investment Position of the United States (in Billions of Dollars):

U. S. Investment Abroad:

Long-term investments: Direct

Foreign dollar bonds

Foreign dollar bonds

Miscellaneous private

Total long-term

Private

Total U. S. assets abroad

* Valued at par.

* Market value.
Short-term:

Total short-term

n.r. Not reported.

Foreign Investment in U. S.:

$\begin{array}{rr}\text { Dec. } & \text { Sept. } \\ 1939 & 1944 \\ 7.0 & 7.3 \\ 3.8^{*} & 1.7^{* *} \\ \text { n.T. } & 1.0 \\ \text { n.5. } & .6 \\ 10.8 & 10.6 \\ & 0.3 \\ .6 & .2 \\ .6 & .5 \\ 11.4 & 11.1\end{array}$
Position (1945) 75 Mag. of Wall ST. 78, 79.

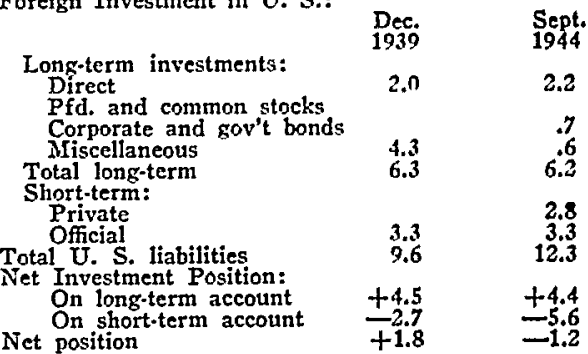


following the war of 1914, and has been perpetuated in the doctrine of sanctions which is common to both Article 16 of the Treaty of Versailles and to the United Nations Organization. That warfare disclosed extraordinary ingenuity in devising trade barriers of all kinds which placed the foreign trader at the mercy of government policy. This unfair competition finally ended in full war, international and revolutionary. It is a misfortune that the danger of economic warfare seems to be continued in the principles of the Potsdam Declaration, not to speak of the threats inherent in the San Francisco Charter.

And here we find that inconsistency to which attention has already been called. While exerting enormous efforts to lift from the world those shackles on international commerce which the r930's developed in such profusion, political arrangements are made which tend to stifle these efforts. To be sure, the political arrangements are not immutable, but no trade can advance without the restoration of a reasonable measure of confidence among the warring nations, a realization that the peoples of all nations must be allowed to eat and to live under conditions commensurate with their social advancement, a determination to suppress the instincts of vengeance and to avoid confusing retribution against governments with retribution against private citizens, an appreciation that economic nationalism, promoted rather than retarded by the treaties of $19 \mathrm{Ig}$, is out of harmony with current necessities for wider regional exchanges, a dissipation of the fear of political extinction or enslavement by the device of "enforcing" peace by some nations upon others. Merely to mention some of these underlying political necessities of an economic peace will indicate the magnitude of the problems facing the post-war world.

More than trade itself, foreign investment is dependent on stable political conditions and the reign of law. Even in these hectic times people must eat and work if they can, so that some exchange of food and raw materials for the products of industry is bound to continue in the face of all handicaps. Not so with foreign investment and the migration of capital, which at the first sign of maltreatment is likely to dry up. And yet large areas of the world are unable to create out of their own resources that surplus wealth which would make dependence on foreign capital unnecessary. Particularly is this true of agricultural countries beginning an industrial development. It was true of the United States during the nineteenth century, when many American railroads and industries were largely dependent upon European capital. Europe and Asia, since the war, hardly present inviting quarters for foreign investment. The nineteenth century, admittedly one of the most remarkable of all, had in many ways a better comprehension of the needs of the human being and of intelligent ways to meet those needs than the twentieth century seems to display. It was then realized that since the free flow of capital was indispensable to the exploration and exploitation of undeveloped areas, political and legal conditions must be created which, while naturally giving no assurance against economic risks, would nevertheless afford some security against political destruction. And if local law proved only an ostensible and not a real protection against arbitrariness, 
discrimination and denial of justice, international law came to the investor's aid to assure him a measure of due process of law. Under such conditions the countries where capital accumulated and the countries that needed this capital both profited by the stability which brought the investment and the resulting trade.

Governments at first took but little interest in the enterprise and made justifiable distinctions between contractual and economic risks taken with open eyes or necessarily incurred, and exceptional tortious or political risks against which the citizen could justifiably ask protection both locally and internationally. Even in such matters as indirect or portfolio foreign investments, of which American citizens own about $\$ 4$ billions, the custom has been not to interpose against unavoidable defaults, of which Americans have been the victims on a large scale, but to protect and support the bondholders against bad faith, diversity of security or pledges, arbitrary repudiation or rank discrimination.

Direct Investments Abroad by American Citizens. In the matter of direct investments, the force of circumstances and enterprise has made American citizens the owners of about $\$ 7$ billions worth in foreign countries, distributed among industries fostering communication and transportation, manufacturing, mining, agriculture and miscellaneous enterprises. About two-thirds of the total, as is the case with portfolio securities, is invested in the Western Hemisphere, much in Canada but most in Latin America. What Latin-American countries do is therefore of great importance to the whole institution of foreign investment and the major problems have arisen in that quarter.

So widespread and common was the pre-war habit of having nationals or national capital abroad, that a great body of law has grown up around the practice, determining the legal relation between the foreign element and the local government on the one hand, and the foreign element and its own government on the other hand. Finally, international law has established by precedent the relation between the two governments arising out of this investment. Without undertaking to analyze this complex of legal relations, it may be said that the alien is in principle subject to the local law and has no cause for international complaint unless he is discriminated against, unless the advantages of the local law are denied him, unless he is the victim of an outrage, initiated or supported by the local government. The international law has something to say to control the divagations and illegalities of local law or administration-but only in these exceptional cases of arbitrariness, however disguised, which expose the foreigner to discriminatory or intentional mistreatment. The practice is now so definitely controlled by law that the Latin-American nations have little, if anything, to fear from its application by arbitral tribunals or Foreign Offices; if there have been in the nineteenth century occasions when forceful intervention has made them perform obligations against their wills, the shoe is now distinctly on the other foot. Too many of them desire the advantages of foreign capital, without assuming corresponding responsibilities.

Legal Implications of Non-Intervention Policy. There is at the moment an in- 
tellectual controversy between a small Latin group that maintains that Secretary Hull, in signing treaties at Montevideo and Buenos Aires providing for nonintervention by one country in the affairs of another on this continent, and providing that the foreigner may never claim better treatment than the national, has abandoned the right of diplomatic interposition on behalf of injured American citizens. This answer was made by Mexico in contesting the American notes of 1938 , protesting against the confiscation of agricultural lands by giving the owners practically worthless bonds and later only a receipt. Secretary Hull's reply was that the treaty of Montevideo did not expose foreigners to the risk of arbitrary mistreatment, whatever nationals might have to suffer. The confiscation was settled by a compromise payment by Mexico extending over a period of years, without admitting, however, that any international wrong had been committed. This matter may come back to plague us. ${ }^{14}$

Nationalization Movement in Latin America. We have witnessed in recent years the effort of certain Latin-American countries to take over large foreign-owned properties on one excuse or another, as an alleged penalty for failure to observe the local law, for alleged defect of title, for alleged breach of contract, for alleged superiority of the public need. Unless such expropriations are closely ${ }^{-c o n t r o l l e d ~ a n d ~}$ checked by the utmost good faith, they are likely to lead to complete loss of confidence, the withdrawal where possible of foreign investments, and political consequences of an unpleasant character. It is a nice and often difficult question to determine how far retroactive laws challenging vested rights can be sustained in international law. But when the country of the investor finds itself unwilling for political reasons to insist upon the rule of law, and thus condones a local disrespect for the rights of foreigners, this conflict between politics and law necessarily impairs the security of foreign investment. If private investment is thus discouraged and public funds are sought from or advanced by a foreign country, the borrower may be inviting what in time may become a new imperialism. The local state is in no danger from private capital; the acceptance of foreign government capital may have political effects. ${ }^{15}$

It is not necessary now to examine the local obligations which the foreign investor incurs. At one time it was thought that the combination of foreign cap-

${ }^{14}$ Cf. Freeman, Recent Aspects of the Calvo Doctrine and the Challenge to International Law (1946) 40 AM. J. INT. L. I2I.

${ }^{15}$ The last paragraph of the minority report on the bill to increase the lending authority of the Export-Import Bank, SEN. REP. 2005, 76th Cong., 3rd Sess. (Aug. 6, 1940) reads as follows:

"6. We wish to make clear that we approve Secretary Hull's sincere and effective policy of promoting friendship with South American countries, a united military front, and a united opposition to totalitarian government, but we say that the lending of money to those countries is not an essential part of that policy or an advisable part of that policy. We say that it is futile, wasteful, and unwise; that it will seriously injure and not assist, the producers of South America and the farmers of North America. If the only way we can maintain a good-neighbor policy is by lending our neighbors money, then the whole structure is based on sand and will be washed away the moment the loans stop. We know as individuals that the poorest way to make a man a good neighbor is to lend him money. It is far more likely to make him your enemy for life. The same result has come in the past from international loans and is bound to come in the future." 
ital and technical skill with local labor, exploiting natural resources or industry, brought an advantage to the country, which it usually recognized by law and by contract. Now, in these new days, there seems to be an impression that the foreigner must go beyond the law or his contract and supply public welfare institutions for the workers or for the local population which the state may fail to provide. As a matter of fact, large-scale enterprises have been philanthropic and far-sighted and have voluntarily undertaken to promote the social welfare and medical care of their employees and their families, and build even public works, often beyond the requirements of the labor law or their contract. But if it should come to be the practice that foreigners must submit to ever increasing burdens and impositions limited only by local political discretion, then foreign investment will become a snare and a trap for the unwary. Economic nationalism in Latin America has already made foreign investment in many respects precarious; if continued, those countries may kill the goose that laid the golden egg and expose themselves to new forms of political imperialism.

Apart from tax discriminations, now largely alleviated by local law or by treaty, the most subtle ways of making the owner of a direct foreign investment uncomfortable is to compel him to comply with the local labor laws under penalty of expropriation. These labor laws are allegedly designed to promote the interests of the working man, and at the same time to cut down the privileges of foreign capital. They therefore meet with considerable approval at home, but since only large companies can run the risk, they are likely either to dry up foreign investment or to shut off the flow of foreign capital. Under the guise of labor laws, foreign enterprises are obliged to take over a large part of the social welfare obligations which normally fall upon the state. In general they must train natives to operate the industries, and afford the local working man a large measure of recreation, medical care for families and other obligations designed to afford the working man a high standard of living. Since only the few can bear these burdens, private foreign investment is likely to drift into the hands of large corporations, who alone can bear the risk. If the foreign corporation finds the conditions intolerable, it is tempted to withdraw its investment. This may be done for it by expropriation or inhospitality so great that it voluntarily withdraws or refrains from further investment. In Mexico, in the case of the oil properties, the local law was largely set aside to accomplish an industrial expropriation which fortunately for Mexico acquired the advantage of the European war to prevent open foreign intervention or arbitration. The local country can thus gain immense profits out of hand, but it is questionable how far such methods nullify that confidence which is necessary to obtain capital. There is some reason to believe that Mexico regrets the expropriation it undertook some ten years ago. If other countries are minded to follow Mexico's example, they are likely to encounter open intervention from foreign countries. Foreign capital is easy to frighten off by arbitrary action.

Calvo Clause. Partly in order to avoid foreign intervention, the countries of 
Latin America have by contract, statute, constitution, and treaty adopted a provision by which resort must be had to the local courts and diplomatic intervention foresworn, as a condition of doing local business. While this first applied only to revolutionary damages, designed to avoid discrimination in favor of the foreigner, it has been extended to all business relations. Most Foreign Offices probably take the view that the clause merely incorporates international law into the transaction and does not foreclose diplomatic interposition in the event of a denial of justice. The cases are almost equally divided. But the signature of the clause induced the Mexican arbitral tribunal in the North American Dredging Company case and in the Mexican Union Railway case, to conclude that the clause had some value in that the signatory corporation must at least try to avail itself of local remedies as the condition of an international claim, even though the protocol of agreement excludes the necessity of resort to local remedies as a normal condition of an international claim. Whether the South American countries have gained much by insistence upon the clause is a debatable question.

The devices employed to make foreign capital uncomfortable must, in the interests of local industry, not be carried to excess; otherwise, private investment is likely to cease. It cannot afford to run the political risks which capital-hungry countries are likely to place upon it. 
$x$ 